\title{
Notes
}

\section{The International Law of Blockade: New Guiding Principles in Contemporary State Practice}

\author{
Michael G. Fraunces
}

For more than four hundred years, nations have conducted naval blockades to deny enemy warships access to the open ocean and to thwart all trade between their enemies and other states. By curtailing their enemies' trade, blockading nations also harm the interests of neutral states. Blockades cause neutral states to lose revenue as their trade with blockaded trading partners is stopped. Blockades also make trade with other neutral states more costly by forcing neutral ships to travel long distances around blockades or to submit to time-consuming searches of their ship and cargo. The damaging effects of blockades often lead neutral states to enter conflicts to protect their interests. The law of blockade seeks to minimize this conflict by balancing the competing interests of neutral and blockading states. ${ }^{1}$

As customary law, traditional, pre-World War I (WWI), blockade law developed out of the tension between a blockading state's assertion of a practice and a neutral state's acceptance or rejection of that practice. In time, five principles emerged that both regulated the establishment and enforcement of blockade and created reciprocal neutral and belligerent rights during blockade. ${ }^{2}$ As the powerful maritime nations further experienced blockade, not only as blockading states, but also as neutrals, they came to recognize the value of the traditional principles in balancing these competing interests. Eventually, these

1. A.C. BeLL, THE BLOCKADE OF GERMANY 1914-1918, at 2-3 (1937).

2. See infra Part I. 
states publicly acknowledged the traditional principles as their own national law. This in turn raised expectations of appropriate blockade behavior and reduced conflict between neutral and blockading states.

The traditional principles were deeply rooted in technology. Prior to WWI, blockade law was based upon the use of surface warships. These ships, powered by sail or steam, patrolled the enemy's coast to intercept vessels entering or leaving its ports. Blockading warships captured violators and transported each ship, cargo, and crew to a control port for disposition by a national prize court. ${ }^{3}$ Generally, ships and cargoes were confiscated, enemy crews imprisoned, and neutral crews returned to their originating state.

By WWI, however, the introduction of new technology radically altered blockade practice. The defensive use of submarines, airplanes, mines, and missiles forced blockading warships to patrol a much larger blockade area. ${ }^{4}$ The offensive use of these weapons necessitated blockade zones within which all vessels were sunk indiscriminately. ${ }^{5}$ Because the traditional law was based on pre-WWI practice, the new blockade forms rendered the traditional law obsolete. Without law to guide them, the actions of both blockading and neutral states grew increasingly unpredictable and violent.

Today, three developments further exacerbate this problem. First, the growing interdependence of the world's economies and their reliance on merchant shipping makes blockade a more valuable weapon. Second, the proliferation of modern weapons into the hands of more and more nations ${ }^{6}$ enables many new states to conduct blockades. Third, the seeming end to the Cold War increases the probability of maritime conflicts as the world adjusts to a new order. As these developments spawn new blockades and result in actual clashes between neutral and belligerent nations, a new, explicit law to guide states becomes imperative. In an effort to restore predictable blockade behavior between states and thereby reduce future violence at sea, this Note clarifies the principles which comprise the existing law of blockade. Part I examines the development of traditional blockade law based upon pre-WWI practice. Part II describes the post-WWI adjustments to practice forced by the

3. Prize courts are nationally constituted judicial bodies that apply international law to captured ships and cargo. JAMES W. GARNER, PRIZE LAW DURING THE WORLD WAR 9 (1927).

4. See 2 D.P. O'CONNEl, THE INTERNATIONAL LAW OF THE SEa 1152 (1984); see also W.T. MALLISON, STUDIES IN THE LAW OF NAVAL WARFARE: SUBMARINES IN GENERAL AND LMITED WARS $57-$ 60 (1966).

5. The term "blockade zone" is used throughout this Note because of the perceived inadequacy of the more commonly used term "exclusion zone." Blockade zones are declared areas of ocean off-limits to all enemy and neutral vessels established to achieve the historical purpose of blockade-economic interdiction. Exclusion zones also have been described this way. Maxwell Jenkins, Air Attacks on Neutral Shipping in the Persian Gulf, 8 B.C. L. REv. 517, 527-28 (1985). However, exclusion zones are more generally described as zones established by belligerents to limit the area in which conflict takes place, without mention of any blockade purpose. W.J. Fenrick, The Exclusion Zone Device in the Law of Naval Warfare, 24 CAN. Y.B. INT'L L. 92 (1986).

6. See generally MICHAEL A. MORRIS, EXPANSION OF THIRD-WORLD NAVIES 67-78 (1987) (increasing proliferation of modern weapons and weapons platforms to developing states since mid-1960's). 
introduction of new technology. Finally, Part III distills the existing blockade principles through an analysis of this post-WWI practice.

\section{The TRAditional LAW OF BLOCKADE}

From the first formal blockade by the Dutch in $1584^{7}$ until the start of WWI, states conducted blockades by preventing all access to or departure from an enemy port using a cordon of warships just off the enemy coast. ${ }^{8}$ While blockade practice started in 1584 , the law of blockade did not emerge for over a century. During these early years, blockading states chose various methods of blockade. They issued proclamations or similar instruments to inform neutrals of the nature of their blockade and of what conduct violated its conditions. Due to their obvious one-sidedness, blockades frequently led to friction and conflict between neutral and blockading states. ${ }^{9}$

As blockades became more common in the late seventeenth century, a need for general rules became apparent. ${ }^{10}$ Early international law scholars, who previously had concerned themselves with justifying the practice itself, ${ }^{11}$ sought to reconcile the belligerent's desire to interrupt its enemy's line of supply with the neutral's interest in continuing to trade with other states. ${ }^{12}$ These analyses of blockade practice formed the early basis of what eventually became known as the traditional law of blockade. ${ }^{13}$

It was actual state practice, however, that provided the core of the traditional law. In the late seventeenth century, neutral states began to respond to belligerent assertions of particular blockade practices. By remaining silent, neutrals acquiesced to a practice. By publicly protesting and stepping into a conflict, neutral states signaled their rejection of a practice. Over time, the process of assertion, followed by acceptance or rejection, led to the recognition of the following general principles governing a lawful blockade: (1) proper establishment; (2) adequate notice; (3) effective enforcement; (4) impartial application; and (5) respect for neutral rights. ${ }^{14}$

7. While the origins of "siege from the sea" can be traced to ancient times, the Dutch blockade of Flanders in 1584 is considered the first formal blockade. This is because unlike the ancient concept of "siege from the sea," the Dutch intended to cut off all trade to Flanders' ports without intending to invest these ports with land forces. James F. McNulty, Blockade: Evolution and Expectation, in 62 U.S. NAVAL WAR COLLEGE INTERNATIONAL LAW STUDIES 172, 174 (1980).

8. This blockade is commonly known as a "close" blockade. ROBERT W. TUCKER, THE LAW OF WAR AND NEUTRALITY AT SEa 285 (U.S. Naval War College Int'l Law Studies No. 50, 1955).

9. See, e.g., McNulty, supra note 7, at 175 (describing Dutch decisionmaking process in 1630).

10. See D.P. O'CONNEll, THE INFLUENCE OF LAW ON SEA POWER 16, 17 (1975)

11. See, e.g., JOHN WESTLAKE, INTERNATIONAL LAW 222 (1907) (describing justification of Dutch blockade of 1584 by most renowned of early publicists, Grotius).

12. See L.A. ATHERLEY-JONES, COMMERCE IN WAR 92-98 (1907).

13. McNulty, supra note 7, at 174; see also ATHERLEY-JONES, supra note 12.

14. See ATHERLEY-JONES, supra note 12, at 192-252 (development and acknowledgement of blockade law in national prize courts). 
The major maritime powers acknowledged and enforced these traditional principles in their national prize courts. ${ }^{15} \mathrm{By}$ articulating how a particular state enforced its blockades and how it expected other states to enforce them, the prize courts raised expectations concerning the rights and duties of belligerents and neutrals. As further practice demonstrated the value of adhering to the traditional principles-in balancing divergent interests and reducing conflict and misunderstanding between belligerent warships and neutral merchants ${ }^{16}$ - they acquired the status of customary international law. ${ }^{17}$ Until the start of WWI, maritime nations relied on these traditional principles to guide them in the conduct of blockade.

\section{A. The Traditional Principles of Blockade}

In spite of the general recognition of the principles before 1800 , no formal international agreement on any of the five principles of blockade law existed until $1856 .{ }^{18}$ Before that time, and really until 1909 , disagreements between the Continental powers and the British on specific application of the five principles prevented formal international acknowledgement of them. ${ }^{19}$ Finally, in 1909, the major maritime powers met in London to codify the customary law of blockade and set down five guiding principles.$^{20}$ Although the participants to the London Conference signed the resulting Declaration of London, disagreement in the British House of Lords over future blockade practice prevented final ratification. ${ }^{21}$ Nonetheless, the Declaration remains as the only collective recognition of the traditional principles of blockade law. ${ }^{22}$ For this reason, this Note uses it to facilitate further discussion of the traditional law of blockade.

15. Id.

16. "The rules of law enhance the deterrence by establishing boundaries of conduct within which power can be demonstrated without inducing panic or provoking incidents likely to lead to instantaneous violence." O'CONNELL, supra note 10 , at 61 .

17. See MALlison, supra note 4, at 15-16 (describing process by which customary law is formed).

18. Declaration Respecting Maritime Law, Apr. 16, 1856, reprinted in THE LAWS OF ARMED CONFLICT 787 (Dietrich Schindler \& Jiri Toman eds., 1988) [hereinafter Schindler \& Tolman] (recognizing principle of effectiveness; blockades must be "effective to be binding").

19. Although states generally agreed on the principles themselves much earlier, they could not agree on the practical application of the principles to the extent that would have enabled them to formally acknowledge them. See, e.g., ATHERLEY-JONES, supra note 12, at 100-05 (describing strenuous resistance by state leaders to widely divergent views of adequate notice).

20. Naval Conference of London, Declaration Concerning the Laws of Naval War, Feb. 26, 1909, arts. 1-21 (never ratified) [hereinafter Declaration of London], reprinted in Schindler \& Tolman, supra note 18, at 845, 846-47 (Article 8-establishment; Articles 9, 11, 16-notice; Articles 2, 3-effectiveness; Article 5-impartiality; Articles 1, 18, 19-neutral rights).

21. See BELL, supra note 1 , at 23.

22. John Colombos, The Actual Value of the Declaration of London of 1909, 12 REVUE HELLENQUE DE DROIT INTERNATIONAL 10, 20 (1959); see also GARNER, supra note 3, at 160-61; McNulty, supra note 7 , at 184 . 
The first principle, that of establishment, limited the right to establish a blockade to states openly engaged in hostilities. ${ }^{23}$ Closely linked to the concept of establishment was the principle of adequate notice. Generally, the commander of a blockading force initiated the process by issuing a formal declaration. This declaration informed both neutral and blockaded nations of the area to be blockaded and the date of commencement. ${ }^{24}$ After a short grace period in which neutral vessels were allowed to leave the blockaded port unhindered, the commander stationed a suitable number of warships off the enemy port or coast. This step completed the formal process of establishing a blockade. ${ }^{25}$

Following establishment and before termination of a blockade, traditional law required effective enforcement. To be effective, a blockade "[had to] be maintained by a force sufficient really to prevent access to the enemy coastline."26 The intent of the principle of effectiveness was to outlaw so-called "paper" blockades in which belligerents declared blockades without the ability to enforce them. ${ }^{27}$ In theory, the principle responded to the unwillingness of neutrals to suffer interruptions in trade unless blockading states "possess[ed] the power and resources, and w[ould] incur the hazard and expense" of placing a sufficient number of warships off the enemy coast. ${ }^{28}$ In practice, because belligerents had a limited number of warships, they had to place their ships just off the enemy coast to maintain an effective blockade.

The traditional law also required impartiality, which imposed a duty to apply the blockade to all vessels regardless of nationality. ${ }^{29}$ This requirement stemmed from the Continental response to the onerous British practice in the eighteenth and early nineteenth centuries of barring vessels from certain ports while allowing British commercial interests to continue trading there. ${ }^{30}$ The principle of impartiality, eventually accepted by the British, made such commercial blockades unlawful.

Unlike the first four principles, the requirement to respect neutral rights represented a more complex tradeoff between neutral and belligerent rights and duties. Generally, the blockading force had the right to prevent all neutral trade

23. L. OPPENHEIM, INTERNATIONAL LAW 775 (H. Lauterpacht ed., 7th ed. 1952); see also Declaration of London, supra note 20, art. 9; FRANCIS H. UPTON, THE LAW OF NATIONS AFFECTING COMMERCE DURING WAR 277 (London, Methuen \& Co. 1863).

24. J.A. HALl, THE LAW OF NAVAL WARFARE 85-86 (1914); see, e.g., The Neptunus, 165 Eng. Rep. 256 (K.B. 1799). While major maritime powers generally accepted the principle of notice, its practical application was often in dispute. See ATHERLEY-JONES, supra note 12, at 100-05; see also OPPENHEM, sUpra note 23, at 776 (describing divergent views of notice between Continental powers and those of Britain, United States, and Japan).

25. HALL, supra note 24 , at 85 .

26. Declaration of London, supra note 20, art. 2; see also HALL, supra note 24, at 81-82.

27. TUCKER, supra note 8, at 288; see also OPPENHEI, supra note 23, at 778-79.

28. UPTON, supra note 23 , at 278.

29. Declaration of London, supra note 20 , art. 5; see also HALL, supra note 24 , at $83-84$; $c$. The Rolla, 165 Eng. Rep. 963, 966-67 (K.B. 1807) (blockade is a "uniform universal exclusion of all vessels not permitted by law" to pass).

30. McNulty, supra note 7 , at 176 . 
directly with the blockaded port or coast. In return for respecting that right, neutrals retained the right to trade with other neutral countries. As a result, blockading forces could not extend their blockade to block access to neutral ports. ${ }^{31}$

More specifically, the right of a belligerent to impede a neutral vessel varied depending on the location of the neutral vessel with respect to the blockade when challenged by a belligerent warship. In the area between the ships of the blockading state and the enemy coast, a belligerent had the right to "capture" any vessel attempting to breach the blockade either inward or outward. ${ }^{32}$ In the case of a breach outward, the vessel that broke the blockade was "liable to capture so long as she [was continuously] pursued by a ship of the blockading force." 33

Outside the blockade area and on the high seas, ${ }^{34}$ belligerents relied on the practice of "visit and search" 35 to stop vessels suspected of carrying "contraband" to the enemy. ${ }^{36} \mathrm{~A}$ belligerent warship sailing on the high seas had the right to visit and search all merchant vessels. Merchants found carrying enemy contraband were captured and escorted to the belligerent's nearest home port. The belligerent nation's prize court then determined the fate of the captured ship and cargo. ${ }^{37}$ In cases where merchants resisted either capture or visit and search, the blockading force was entitled to pursue and, if necessary, damage or destroy the vessel to force the ship to submit. ${ }^{38}$

31. Declaration of London, supra note 20, arts. 1, 18. See generally GODFREY LUSHINGTON, A MANUAL OF NAVAL PRIZE LAW 43 (1866) (describing when blockades considered null and void).

32. Declaration of London, supra note 20, art. 17. Captured vessels surrendered both ship and goods if found violating the blockade. HALL, supra note 24, at 92 . Fishing vessels, hospital ships, and small boats engaged in local trade were exempt from capture. GARNER, supra note 3, at 240; see also CHARLES C. HYDE, MARTIME WARFARE 151-65 (1918) (questioning legality of capturing vessels carrying foodstuffs).

33. Declaration of London, supra note 20 , art. 20.

34. High seas includes all seas beyond the boundary of any country. BURDICK H. BRITIN, INTERNATIONAL LAW FOR SEAGONG OFFICERS 474 (1986).

35. Visit and search is distinct from blockade. Generally, belligerent warships could stop and search merchant vessels anywhere on the high seas for contraband going to the enemy's army. Vessels found carrying contraband were captured. The ship and the cargo were then subject to condemnation proceedings conducted by the blockading nation's prize court. See generally ATHERLEY-JONES, supra note 12, at 299389; UPTON, supra note 23 , at 334-48; HALL, supra note 24, at 110-27.

36. Simply stated, there were three types of contraband: (1) "absolute contraband" or goods used exclusively for war; (2) "conditional contraband" or goods easily converted to a warlike use; and (3) "free goods" or all goods useless for war purposes. Belligerents had the right to capture and condemn or confiscate all absolute contraband found in route to the enemy. The same was true for conditional contraband unless the owner of the goods could rebut the presumption that the goods were destined for military use. HALL, supra note 24, at 93-96. See generally ATHERLEY-JONES, supra note 12, at 1-91 (discussing British, Continental, and U.S. law of contraband); UPTON, supra note 23, at 327-34 (discussing U.S. law of contraband).

37. In cases of capture following visit and search, belligerents could confiscate the contraband cargo, the ship, or both, depending on the circumstances. UPTON, stupra note 23, at 333; see also ATHERLEY-JONES, supra note 12, at $379-84$. In breach of blockade cases, belligerents generally confiscated both the ship and the cargo. HALL, supra note 24, at 92; see also ATHERLEY-JONES, supra note 12, at 389-92.

38. MALlison, supra note 4, at 100; see also HALL, supra note 24, at 113; William O. Miller, A New International Law for the Submarine?, U.S. NAVAL INST. PROC., Oct. 1966, at 97. 


\section{B. Why the Traditional Principles Provided Balance}

There were two primary reasons why the traditional principles adequately balanced neutral and belligerent interests prior to WWI. Most notably, the period was marked by little change in the technology and tactics upon which the traditional law of blockade was based. States enforced blockades using surface warships, which stayed close to the coast. Even while remaining close, the warships could easily sail beyond the range of coastal batteries. Despite the improvement in the accuracy of land-based cannons and the fundamental shift from sailing vessels to faster, steam-powered ships, ${ }^{39}$ existing blockade form and tactics were never seriously threatened. Since little change in the practical application of the law was necessary, the traditional principles continued to suffice.

Politics and power also played an important role in the development and long-term effectiveness of the law. Since there were only a handful of maritime nations powerful enough to count in the law formation process-belligerent assertion of a practice, followed by neutral acceptance or rejection of it-blockade law tended to serve their long-term interests. ${ }^{40}$ These states shared common interests in empire-building, and blockade law reflected their imperial pursuits. As belligerents, they used blockade law to help their navies establish overseas colonies. As neutrals, they used the law to help their navies keep trade routes open to protect their overseas interests. In time they recognized how quickly their roles as belligerents or neutrals reversed and realized the value of respecting both rights. Under such conditions, the law of blockade flourished.

From the late seventeenth to the early twentieth century, these stable conditions provided an ideal climate for the traditional principles to balance neutral and belligerent rights. Neutral powers generally respected blockades and allowed their merchant vessels to be visited and searched. Similarly, belligerents generally respected neutrals' rights to engage in neutral commerce. ${ }^{41}$ By adhering to the five traditional principles, the actions of blockading forces and neutral merchant vessels became more predictable and less likely to lead to further conflict. As WWI erupted across Europe, however, this previously ideal climate began to change.

39. See GIUSEPPE FIORAVANZo, A History of NAVAL TACTICAL THOUGHT 106 (Arthur W. Holst trans., 1st ed. 1979) (other weapons such as mines and submarines were developed in latter half of 19th century, but were too crude to threaten effectively supremacy of surface ships).

40. In the 17th and first half of the 18th centuries, while establishing their empire, the British dominated the seas and used the law of blockade to further their aims. During this period, the British were not sympathetic to neutral interests. Once they established their empire, however, they sought to protect it. By becoming more amenable to neutral interests, the British helped to establish a more balanced law of blockade. See McNulty, supra note 7, at 176-78.

41. H.A. SMTTH, THE LAW AND CUSTOM OF THE SEA 75 (1950); see also O'CONNELL, supra note 10, at $18-19$. 


\section{Evolving State Practice and ITS EFFect on THE TRADITTONAL LAW OF BLOCKADE}

The British and German blockades in WWI marked the beginning of significant changes in blockade practice. Each nation discarded traditional blockade form in an effort to stop all maritime trade to the other. The British positioned their warships hundreds of miles from the German coast, in effect blockading the entire North Sea. The British chose this expanded blockade form to avoid losses from German submarines and defensive mines. ${ }^{42}$ In response, the Germans declared a zone of blockade around the British Isles. ${ }^{43}$ They enforced the blockaded area with submarines because their surface navy lacked sufficient strength to control the ocean surface. ${ }^{44}$ At first, the Germans adopted measures to avoid accidental sinkings of neutral vessels, ordering their submarines to visit and search and capture merchant vessels found within the zone. ${ }^{45}$ The British countered by arming their merchant vessels and directing them to resist German submarine boarding attempts. The British tactic worked. British merchants successfully thwarted many attacks and sank several surfaced submarines as they prepared for visit and search. ${ }^{46}$ Unwilling to risk further losses and afraid accidental sinkings of neutral vessels would bring the United States into the war, the Germans discontinued submarine visit and search and, for a time, suspended enforcement of the blockade altogether. Eventually, however, German desperation outweighed fears of neutral retaliation, and the Germans ordered their submarines to sink indiscriminately all vessels found within the declared zone. ${ }^{47}$

Neutral governments condemned both the British practice of conducting a "long-distance" blockade ${ }^{48}$ and the German enforcement of a "blockade zone." Following WWI, the maritime powers outlawed German blockade practice by requiring submarines to visit and search and to provide for the safety of the crew before sinking merchant vessels. ${ }^{49}$ While no similar agree-

42. BELL, supra note 1, at 30-31 (plan to conduct traditional, close-in blockade of German coast abandoned prior to start of WWI because of likelihood of severe losses in first few weeks of war).

43. The Germans called their zone a "war zone," but for purposes of this Note, any zone declared by a state to effect the purposes of blockade will be termed a "blockade zone." See R.H. GIBSON \& MAURICE PRENDERGRAST, THE GERMAN SUBMARINE WAR 1914-1918, at 27-28 (1918).

44. MALLISON, supra note 4 , at $62-63$.

45. Id. at 63-64.

46. Id. at 66-67.

47. See GIBSON \& PRENDERGRAST, supra note 43, at 137. The Germans attempted an interim step before deciding to sink all vessels found within the zone. They required submarine commanders to ensure merchants were armed before sinking them. This solution was impractical, however, because the British merchants hid their guns until the submarine surfaced and started to attempt visit and search. MALLISON, supra note 4, at 67 . Concern over the stalemated land battle and the growing effectiveness of the British blockade eventually forced the Germans to institute a blockade zone. See GIBSON \& PRENDERGRAST, supra note 43 , at $81-95$.

48. 2 O'CONNELL, supra note 4, at 1152; see also MALLISON, supra note 4, at 57-60.

49. London Treaty for the Limitation and Reduction of Naval Armaments, Apr. 22, 1930, Part IV, art. 22 , reprinted in Schindler \& Toman, supra note 18, at 881-82. The requirements were reaffirmed again in 
ment banned long-distance blockades, international law scholars condemned the practice both during and after the war. They asserted that long-distance blockades unlawfully encroached on traditional neutral rights by inhibiting and, in some cases, completely halting neutral trade to neutral ports. ${ }^{50}$

In spite of the condemnations, the success of the British long-distance blockade and the near success of the German blockade zone in WWI spurred the Allies and Axis to use these blockade forms at the outset of World War II (WW II). ${ }^{51}$ Again, neutral governments condemned these practices during and after the war, particularly the use of blockade zones. While long-distance blockades simply inconvenienced neutrals, blockades zones failed to protect the rights of neutrals, resulting in the loss of neutral ships, cargoes, and sailors. ${ }^{52}$

Nevertheless, belligerents today continue to enforce blockades from long distance or through blockade zones. They do so because of three twentiethcentury developments in maritime warfare: first, the growing importance to belligerents of conducting economic warfare in conjunction with armed conflict; $;^{53}$ second, the introduction of a large array of new weapons to the maritime battlefield; ${ }^{54}$ and third, the proliferation of modern weapons to less powerful nations incapable of conducting traditional blockade. In combination, these three developments have forced states to replace traditional blockade form with long-distance blockade or blockade zones.

\section{A. The Growing Importance of Economic Warfare}

Economic warfare became more important as states relied more heavily on their home economies to prosecute a war. By the start of the twentieth century, weapons construction had become a complex operation. To make tanks, airplanes, warships, and other necessities of modern warfare, the military required civilian workers and factories to manufacture them. Most states acquired the raw materials to make the weapons from overseas sources and transported them home on civilian merchant ships. As the civilian war effort grew in importance, belligerents began to attack factories, merchant ships, and other economic

1936. London Protocol, Nov. 6, 1936, art. x, reprinted in id. at 883-84.

50. MALLISON, supra note 4, at 70; see also E.G. Trimble, Violations of Maritime Law by the Allied Powers During the World War, 24 AM. J. INT'L L. 79 (1930).

51. The British supplemented their long-distance blockade with a vessel certification system called "Navicert." Under the Navicert system, the British required each ship, prior to leaving port, to submit to inspection for contraband by British inspectors. The in-port inspection replaced the traditional visit and search procedure at sea. Vessels stopped and found without Navicerts were captured. 2 W.N. MEDLICOTT, THE ECONOMIC BLOCKADE 94-101 (History of the Second World War, United Kingdom Civil Series, 1978).

52. TUCKER, supra note 8, at 297-98. at 63.

53. Robert D. Powers, Blockade: For Winning Without Killing, U.S. NAVAL INST. PROC., Aug. 1958,

54. Id. at 61. See generally ROBERT E. OSGOOD \& ROBERT W. TUCKER, FORCE, ORDER, AND JUSTICE 56-70 (1967). 
targets. The idea was to defeat the enemy in the field through the destruction of its supporting economy. ${ }^{55}$

At sea, the need to damage the enemy's economy enhanced the value of the practice of blockade itself. States began to use blockade to exploit the enemy's Achilles' heel-reliance on surface shipments of raw materials from distant points on the globe. More specifically, blockading states started to enforce a growing list of contraband, ${ }^{56}$ which eventually included most tradable commodities. This made belligerent justification of blockade zones easier since all ships found within the zone could be considered enemy collaborators, violating the blockade by supplying the enemy with contraband. In addition, improved land transportation systems raised suspicions that adjacent states were supplying the enemy. This provided justification for expanding the blockade size to include blocking neutral access to neutral ports.

In the future, blockade may become even more important as the need of a blockading state to stop every merchant ship grows more vital. The recent willingness of ostensibly neutral states to supply not simply technical know-how and materials for weapons construction, but also ready-for-use missiles and other decisive weapons, to the highest bidder portends such a future. As the negative consequences of allowing even one ship to pass uninspected grow more severe, blockading states will become more willing to use the new blockade forms at the expense of neutral interests.

\section{B. The Impact of Weapons Technology on Traditional Blockade}

The development and introduction of the submarine and the mine, and later the airplane and the missile, dramatically affected blockade practice. When these weapons were used by blockaded states to defend themselves, they forced blockading warships to move hundreds of miles from the enemy coast. ${ }^{57}$ The British blockade of Germany in WWI provides an excellent example of this new practice. German mines and submarines led the British to enforce a longdistance blockade by positioning their ships in the English Channel and the Iceland-Hebrides gap where they intercepted merchant traffic to and from Germany and adjacent neutral countries. In WW II, the Germans also attacked the British blockade with airplanes, forcing British warships to abandon the English Channel and move farther out to sea. In both wars, German defensive weapons forced the British to adopt a greatly expanded form of blockade.

55. 2 MEDLICOTT, supra note 51 , at 2.

56. See, e.g., BELL, supra note 1, at 721-44; see also John V. Lovitt, The Allied Blockade, DEP'T ST. Bull., Nov. 19, 1944, at 597.

57. 2 O'CONNELL, supra note 4, at 1151-52; see also SALLY V. MALlisON \& WLLIAM T. MALLISON, A Survey of the International Law of Naval Blockade, U.S. NAVAL INST. PROC., Feb. 1976, at 45, 48; Alexander Holtzoff, Some Phases of the Law of Blockade, 10 AM. J. INT'L L. 53, 57 (1916). 
Until the mid-1960's, the examples of the World Wars remained exceptions to general blockade practice. Before then, relatively few nations possessed the modern naval weapons needed to defend against blockade, ${ }^{58}$ and states with powerful surface navies continued to conduct traditional blockade. Today, however, many states own modern weapons. Moreover, sophisticated naval weapons proliferation to developing states is growing as countries with knowhow increasingly encourage their weapons manufacturers to sell their products to new customers. ${ }^{59} \mathrm{By}$ examining the damaging effects of modern naval weapons on surface ships and with the knowledge that more and more states are acquiring these weapons, it is now clear that, in all but the rarest circumstances, traditional blockade is no longer viable.

The Submarine. Opponent submarines greatly complicated the task of surface warships attempting to interdict enemy commerce. As early as WWI, submarines traveled hundreds of miles beneath the surface undetected. This made slow-moving warships, particularly those patrolling a small area off the enemy coast, highly susceptible to attack.

Modern submarines remain submerged longer, have greater endurance, and are much quieter and faster than their WWI and WW II forerunners. ${ }^{60}$ The increased capabilities of submarines coupled with their proliferation to more and more states makes the threat posed to surface ships even greater today. Aside from the United States and the Soviet Union, forty-one nations now own and operate over 400 submarines. ${ }^{61}$ Of these, over 200 are operated by socalled "developing nations." 62 Many of them are top of the line diesel submarines with improved quieting and great submerged endurance. ${ }^{63}$ These submarines are difficult to neutralize, even when using the most advanced antisubmarine warfare techniques. ${ }^{64}$ As more nations purchase these highly capable submarines, states with powerful surface navies like the United States become less able to conduct close-in blockade.

Defensive Mining. At the turn of the century, blockading warships began to face another stealthy threat, the defensive mine. In both World Wars, Germany and Great Britain sowed defensive mines close to their own coasts to prevent their enemy from attacking their ships when they were most vulnerable, as they entered or left port. The mines were effective. British minefields, for example, forced German submarines to operate father from the British coast

58. See generally MORRIS, supra note 6, at 67-78 (increasing proliferation of modern weapons and weapons platforms to developing states since mid-1960's).

59. Id. at 75 .

60. The sinking of the Argentine cruiser General Belgrano off the Argentine mainland by the British nuclear-powered submarine Conqueror provides a stark example of the effectiveness of submarines against surface warships. Charles W. KobURGER, SEA POWER IN THE FALKLANDS 38 (1983).

61. James Fitzgerald \& John Benedict, There Is a Sub Threat, U.S. NAVAL INST. PROC., Aug. 1990, at 57,58 .

62. Id. at 58 .

63. Id. at 57-58 (Soviets, German, French, and British willing to sell to developing nations).

64. Id. at 62-63. 
and thereby lessened the chance of finding and attacking enemy convoys in the open ocean.

Defensive mining remains an effective and prevalent tactic today. ${ }^{65} \mathrm{It}$ is also relatively inexpensive. Consequently, even the poorest maritime nations use mines to postpone or thwart close-in blockades by powerful surface navies. ${ }^{66}$

Airplanes. By the start of WW II, advances in airplane technology seriously threatened the viability of surface warships. Blockading states responded to this new threat either by sending their planes to destroy or neutralize the enemy air force, which allowed them to press the blockade closer, ${ }^{67}$ or by moving their ships farther away from the enemy coast. ${ }^{68}$ As the range of modern attack aircraft increased beyond one thousand nautical miles, ${ }^{69}$ the latter response grew unworkable for a traditional blockade. Less powerful states did not possess enough surface ships to blockade this larger area. Even when powerful states possessed a sufficient number of ships, the decision to devote so much of their naval resources to a long-distance blockade often was unjustifiable. They needed their surface warships for tasks such as naval bombardment, antisubmarine warfare, convoy escorts, and amphibious assault. ${ }^{70}$ As a result, maritime states discarded close-in blockade by surface ships for other, more efficient means.

65. Although both in the Korean war and in the recent Kuwaiti crisis, the North Koreans and the Iraqis, respectively, planted mines along their coasts for the purpose of thwarting enemy invasion, both conflicts provide excellent examples of the continued effectiveness of defensive mining to fulfill the purposes of blockade. See James J. Hoblitzell, The Lessons of Mine Warfare, U.S. NAVAL INST. PROC., Dec. 1962, at 33, 36 (3000 mines planted by North Korean fishermen prevented 50,000 troops from landing at Wonsan for eight days); J.M. Martin, We Still Haven't Learned, U.S. Naval INST. PROC., July 1991, at 64 (describing damage to U.S. ships from Iraqi defensive mining). See generally J.A. Meacham, Four Mining Campaigns: An Historical Analysis of the Decisions of the Commanders, 19 NAVAL WAR C. REV. 98, 10415 (1967) (analyzing effects of defensive mining by North Koreans at Wonsan). Other examples of recent defensive mining by developing nations are the 1971 Indian mining of Chittagong and the Egyptian minefields placed off Port Said in 1973. MORRIS, supra note 6 , at 48 .

66. Mines are frequently characterized as a "favorite weapon of the weaker or non-naval nation in conflict with a major naval power." Hoblitzell, supra note 65, at 33; see also J.A. Meacham, The Mine as a Tool of Limited Warfare, U.S. NAVAL INST. Proc., Feb. 1967, at 50, 53 (suggesting value of mining to inferior naval powers should not prevent United States from using mines as well).

Mines are extremely cost effective. The mine that struck the USS Princeton during Operation Desert Storm cost approximately $\$ 3000$. While the estimated cost to repair the Princeton is unknown, the cost to build the Princeton was $\$ 948.3$ million. The mine that struck the USS Samuel B. Roberts during the IranIraq War cost less than $\$ 1500$. The cost to transport and repair the Samuel B. Roberts was $\$ 52.1$ million, one-sixth of the cost of building her. Martin, supra note 65, at 64-65.

67. Although not conducted strictly for blockade purposes, the recent Desert Storm Operation illustrates the ability of states with powerful surface navies, once air superiority has been established, to bring their warships close to the enemy coast. See Tom Delery, Away the Boarding Party, U.S. NAVAL INST. PROC., Naval Rev. 1991, at 55, 64-65; see also Norman Friedman, The Seaward Flank, U.S. NAVAL INST. PROC., July 1991, at 81-83 (U.S. surface ships performed various close-in tasks once air superiority established).

68. This was done during the Cuban Quarantine. Carl Christol \& Charles Davis, Maritime Quarantine, 57 AM. J. INT'L L. 525, 528 (1963) (U.S. intercept zone had 500-mile radius).

69. See KOBURGER, supra note 60, at 17 (Argentine Super Etendard airplanes operated against enemy ships 400-500 miles away).

70. See id. at 37, 53 (British surface ships conducted close escort, landing force defense, gunfire support, and antisubmarine patrols while submarines enforced blockade). 
Missiles. Missiles exposed surface ships to dangers that could not be avoided simply by achieving air superiority. Since a missile can be launched from the air, land, or sea, the blockading state must be able to control all three environments to fully protect its surface ships. Even where a state controls the air and the surrounding sea, surface ships remain vulnerable to missile attack from land-based launchers and from launchings by ships moored within a protected port. The sinking of the Israeli destroyer Elath by missiles fired from an Egyptian PT boat in the Arab-Israeli conflict of 1967 illustrates the potency of such missiles. ${ }^{71}$ The Egyptians fired four missiles from Port Said at a range of about thirteen miles from the Elath. All four missiles hit their target. ${ }^{72}$

Since the Elath incident, missile technology and missile defense technology have improved dramatically. Missiles can now travel hundreds of miles before reaching their target at speeds several times the speed of sound. Missiles are also extremely difficult to detect because they can fly just above the ocean surface. Although surface ships now employ a variety of weapons to shoot down or divert missiles before impact, the true effectiveness of missile defense systems has yet to be determined, especially where many missiles are fired simultaneously at one target. ${ }^{73}$ At the very least, blockading warships need time to respond to attacks and, as a result, must be positioned far from the enemy coast.

Today, developing states increasingly purchase and use missiles to defend against blockade ${ }^{74}$ because missiles, like mines, are relatively inexpensive for the defensive punch they provide. This proliferation of missile technology further highlights the growing impracticability of traditional blockade. In the future, powerful states will have only two choices: long-distance blockade, or the substitution of surface ship enforcement of blockades with submarines, mines, airplanes, and missiles.

\section{Long-distance Blockades}

Presently, states assume that when using surface ships to enforce blockades they will have to position their warships far off the enemy coast. To minimize the burden of the greatly expanded blockade size, states using a long-distance blockade form generally make certain accommodations for neutrals. In place of capture, enforcing states visit and search all approaching vessels. Vessels carrying contraband are turned away, while merchants without contraband are

71. Robert D. Colvin, Aftermath of the Elath, U.S. NAVAL INST. PROC., Oct. 1969, at 60, 62.

72. Id.

73. See Michael Vlahos, The Stark Report, U.S. NAVAL INST. PRoc., Naval Rev. 1988, at 63, 66-67 (Stark's close-in weapons system Phalanx not properly employed, but even if it had been, no indication Phalanx would have detected and destroyed missiles given angle of missile approach); see also KOBURGER, supra note 60, at 53-54 (ease of sinking of H.M.S. Sheffield with exocet missile).

74. For example, in the 10 years from 1972 to 1982 , the number of missile-equipped, fast attack craft owned by developing states tripled from 77 to 242 . MORRIS, supra note 6 , at 38-39. 
allowed to pass. In the most recent example of this type of blockade, coalition forces interdicted vessels throughout the Red Sea and northern Arabian Gulf. ${ }^{75}$ Initially, the interdicting ships visited and searched merchants. When a merchant ship resisted such measures, coalition forces used helicopters to insert special forces teams to gain control of the ship and turn it away from its prohibited destination. ${ }^{76}$ The success of the coalition forces' blockade suggests that long-distance blockade remains a viable tactic against recalcitrant enemies. Nonetheless, the large costs and significant resources necessary to enforce a long-distance blockade portend its demise: only blockading states with much stronger surface navies than their opponents will use be able to use it.

\section{Blockade Zones}

The substitution of surface ships with mines, missiles, submarines, and airplanes for blockade enforcement has radically altered blockade form. Instead of a cordon of warships, belligerents now declare a block of ocean along the enemy coast off limits to all vessels. Belligerents create these blockade zones because none of the new weapons can be used to visit and search ${ }^{77}$ or capture merchant vessels. Blockading states simply substitute heightened notice to all states to stay clear of the blockaded area ${ }^{78}$ Neutral and belligerent ships found within the declared zone then become the subject of indiscriminate attack.

Immediately following Pearl Harbor, the United States declared a huge blockade zone encompassing the entire Pacific and ordered its submarines to attack all warships and merchant ships found within the declared zone. After several years, as the invasion of the Japanese mainland loomed, the United States supplemented the submarine effort with a bomber-mining campaign of the main seaways to and from the Japanese coast. The new blockade form proved very effective. ${ }^{79}$

Since the end of WW II, international legal scholars have disagreed on the lawfulness of blockade zones. ${ }^{80}$ Nonetheless, throughout this period, blockade zones have been used regularly in a variety of settings. Moreover, the frequency of this practice is increasing. In 1972, the United States declared a blockade of nine Vietnamese ports, including Haiphong, and used mines to enforce it. ${ }^{81}$

75. Delery, supra note 67 , at 66 .

76. Id. at 68-71.

77. MALLISON, supra note 4, at 37; see also Malcolm Moos, The Navicert in World War II, 38 AM. J. INT'L L. 115 (1944) (visit and search no longer safely conducted at sea due to submarine threat).

78. See, e.g., Bruce A. Clark, Recent Evolutionary Trends Concerning Naval Interdiction of Seaborne Commerce as a Viable Sanctioning Device, 27 JAG J. 160, 165 (1973) (noting importance of notice to merchant ships in mining of North Vietnamese ports).

79. Arnold S. Lott, Japan's Nightmare-Mine Blockade, U.S. NAV. INST. PROC., Nov. 1959, at 39, 46-51.

80. TUCKER, supra note 8, at 298 (blockade zones lawful only as measure of reprisal); see also O'CONNELL, supra note 10, at 167-68. But see MYRES S. MCDOUGAL \& FLORENTINO FELICIANO, LAW AND MINIMUM WORLD PUBLIC ORDER 493-95 (1961) (blcckade zone lawful if minimum destruction of values achieved given legitimate belligerent objectives sought); MALLISON, supra note 4, at 69-74.

81. See O'CONNEL, supra note 10, at 94. 
In 1971 and 1983, the Indians ${ }^{82}$ and the British ${ }^{83}$ in their respective wars against the Pakistanis and the Argentineans effectively employed submarines to enforce blockade zones. The Indians also used missiles launched from patrol boats. Finally, both Iran and Iraq in their recent war declared blockade zones around each other's coast, enforcing the zones with missiles fired from the land, sea, and air. ${ }^{84}$ Given the general outrage against blockade zones and the inherent risk of raising the ire of neutral states by sinking their merchant ships, the question of why blockade zones persist remains unanswered. A closer look at several modern conflicts reveals compelling reasons for their continued and increasing use.

The Germans in WWI asserted the first justification of blockade zones. The zones allowed states unable to control the surface of the ocean to interrupt trade to states whose more powerful surface navies blockaded them. ${ }^{85}$ Similarly, in WW II, because the United States lacked the resources to control the surface of the ocean around the Japanese mainland, it used a blockade zone to cut off the Japanese line of supply. In a more recent example, the Iraqi blockade of the Iranian coast demonstrated the continued employment of blockade zones by lesser powers to strike back at more powerful states blockading them. The greater vulnerability of surface ships due to weapons proliferation suggests that, in the future, fewer states will be able to control the ocean surface even where they are the dominant naval power.

Another reason for the continued and growing use of blockade zones is that they tend to inhibit neutral trade less than long-distance blockades. Longdistance blockades require huge areas of ocean, forcing neutral states either to go around or to submit to visit and search. Alternatively, blockade zones are generally much smaller due to the relative invulnerability of submarines, mines, and missiles. ${ }^{86}$ For example, the United States' mining of Vietnamese ports all took place within North Vietnam's territorial waters. ${ }^{87}$ In contrast, the coalition's blockade of Iraq, enforced with surface ships, encompassed much of the Red Sea and Gulf of Arabia. ${ }^{88}$ While neither blockade form resulted in the loss or damage of a single neutral vessel, the coalition's blockade clearly placed a greater burden on neutral vessels.

In the face of strong criticism and high risk, blockade zones continue to be used. The trend toward greater proliferation of modern weaponry suggests that states will more frequently choose blockade zones over both traditional blockade and long-distance blockade forms.

82. See 2 O'CONNELL, supra note 4, at 1099.

83. See KOBURGER, supra note 60 , at 38 .

84. See Jenkins, supra note 5 , at 546.

85. See supra text accompanying note 44.

86. Critics of this view would probably argue that neutrals are still better off with visit and search than with indiscriminate attack and probable destruction of neutral vessels.

87. Clark, supra note 78 , at 162.

88. Delery, supra note 67 , at 66 . 


\section{E. The Effect of New State Practice on the Traditional Principles}

It is now clear that the combination of new technology, new players, and new objectives has steadily shifted blockade practice away from its traditional form. Consequently, the traditional principles no longer adequately guide state practice. For example, the traditional principles of establishment and effectiveness are meaningless when states set up blockade zones. Traditional establishment required the blockade commander to place warships off the enemy coast before commencing the blockade. Traditional effectiveness demanded a sufficient number of warships to stop all or most vessels entering or leaving port. Since blockade zones do not use surface ships, these two traditional principles have no effect on states using blockade zones.

The growing size of blockade areas and the indiscriminate destruction of merchants found within them has also placed traditional neutral rights in doubt. Long-distance blockades often inhibit neutral trade to neutral ports. Blockade zones allow indiscriminate destruction of merchant ships, eliminating the traditional neutral right of capture when found in violation of blockade.

Because the traditional law fails to guide blockade behavior, states are again relying on the process of assertion of a blockade practice, followed by neutral acceptance or rejection of that practice, to guide them. Just as in the period before acknowledgement of the traditional principles, this process often requires neutral states to express their rejection of a practice through force. While this process is not devoid of law, it is more violent and destructive than blockade practice guided by acknowledged principles. Reduction of future violence between neutral and belligerent states therefore depends upon the uncovering of new principles of blockade law. By then publicly acknowledging these new principles, states can begin to reassert an explicit rule of law at sea.

\section{The NeW PRinciples of THE LAW OF BlockadE}

As in the days before formal acknowledgement of the traditional law, when international legal scholars sought to make clear what constituted a lawful blockade, the first step in uncovering the new principles is to recognize that blockade law is derived from state practice. Unfortunately, the introduction of new technologies, new players, and new objectives onto the maritime battlefield makes analyzing state practice extremely complex. Nonetheless, this Note attempts to derive the new guiding principles of blockade law from a close analysis of state practice.

\section{A. An Analysis of New State Practice}

In the days before WWI, the traditional principles were based on one practice-surface ship enforcement of blockade. Now, the multitude of weapons 
used for enforcement, coupled with the many combinations of national objectives and capabilities in modern conflicts, has created a wide variance in blockade practice. A coherent law of blockade is thus difficult to discern. By examining the process by which states decide on the form and size of their blockade, however, it becomes clear that new, more flexible principles exist to guide future blockade practice.

In general, state decisionmakers evaluate the following factors before setting up a blockade: (1) their objectives; (2) their maritime strength; (3) the geographical setting of the blockade; (4) their enemy's objectives; (5) the maritime strength of their enemy; (6) the burdens placed on neutrals; (7) the maritime strength of neutrals; (8) the expected neutral response to the blockade; and (9) the weapons they will use. In combination, these nine factors help states decide whether to conduct a blockade, and, if so, how it will be conducted. The first eight factors will be discussed together in Section 1 and the ninth factor, the weapons decision, will be discussed separately in Section 2.

\section{The Blockade Decisionmaking Process}

The process of modern blockade decision centers on an effort by state decisionmakers to balance neutral and belligerent interests. In most cases, they employ the following process before establishing a blockade. First, they determine their blockade objectives. These objectives generally reflect the scope of the conflict in which they are engaged. Total wars, in which states fight for national survival, usually result in ambitious blockade objectives. ${ }^{89}$ Conversely, limited wars ${ }^{90}$ usually result in modest blockade objectives. State decisionmakers then examine their own naval capabilities and the geography of the conflict to determine how best to achieve their blockade objectives. Next, they adjust the size and form of the blockade to account for their enemy's ability to break or thwart it. Finally, the decisionmakers calculate the burden such a blockade places on neutral states and estimate the expected neutral response. A substantial risk of strong negative responses by neutrals with powerful navies may cause decisionmakers to reduce blockade size or even to forgo conducting a blockade altogether. Nevertheless, where the need to realize blockade objectives exceeds the expected ramifications of neutral responses, decisionmakers choose the blockade form and size necessary to meet their objectives. WW II, the IranIraq war, and the Falklands conflict illustrate the varying types of blockade resulting from this decisionmaking process.

WW II was a total war in which many traditional laws of war, including those of blockade, were discarded in the name of national survival..$^{91}$ Through-

89. Total war in this context refers to warfare conditions in which both belligerents expend most of their available resources to win the war. See generally ROBERT E. OSGOOD, LIMTTED WAR 88-119 (1957).

90. Limited wars are those fought for well-defined objectives short of a full military effort. Id. at 1-2.

91. See id. at 102-16. 
out the war, the military objectives and capabilities of belligerent states were enormous. The United States and Great Britain sought to control the world's nonmilitary shipping in order to stop completely the supply of goods to the European Continent. ${ }^{92}$ In turn, Germany hoped to restrict the flow of goods from the United States to both Britain and the Soviet Union. Likewise, Japan and the United States attempted to prevent the resupply of each others' troops throughout the Far East. By declaring huge expanses of ocean off-limits, these states obstructed virtually all merchant shipping. Since these five nations also comprised the world's maritime military power at the time, there was no nation or group of nations strong enough to champion the rights of neutrals.

Like WW II, the Iran-Iraq war was a war in which both sides fought for national survival. On land, the desperation of the conflict led them to ignore many basic laws of warfare. At sea, each nation sought complete obstruction of maritime traffic to and from its enemy. ${ }^{93}$ Unlike WW II, however, the belligerents in this war had to adjust the form and size of their blockade to account for the needs and capabilities of powerful neutral states.

Early in the war, both sides declared large blockade zones off the enemy's coast. For a time, these blockade zones provided for the rights of neutrals by allowing Saudi and Kuwaiti oil trade to continue unhindered to the West and Japan. As the war progressed, and Iran realized that both Kuwait and Saudi Arabia were making payments to Iraq in support of its war effort, Iran began to strike Saudi and Kuwaiti oil tankers found outside of their originally declared blockade zone. ${ }^{94}$ In spite of a superior navy and favorable geography, however, Iran never took the affirmative step of completely closing the Straits of Hormuz. The presence of neutral navies in the Indian Ocean forced the Iranians to restrict the size of their blockade zone to allow most neutral traffic to and from Kuwait and Saudi Arabia. Iran understood both the West's need for the continued flow of oil and the West's military capability to ensure that the flow continued. As a result, Iran restricted the area in which it attacked merchant ships to forestall full employment of this neutral strength against it.

The Falklands war was a limited one in which neither nation fought for national survival. In fact, both Argentina and Great Britain purposely limited the scope of the war to prevent the extension of the conflict to the Argentine mainland. Nevertheless, both Argentina and Great Britain declared huge blockade zones around the Falkland Islands..$^{95}$ Neutral states tolerated the large

92. See 2 MEDLICOTT, supra note 51, at 15-17, 23-24 (reciting steps Britain took to pursue this goal).

93. See, e.g., Boleslaw Bozcek, Law of Warfare at Sea and Neutrality: Lessons from the Gulf War, 20 OCEAN DEV. \& INT'L L. 239, 244-45 (1988).

94. The fact that Iran attempted to interdict Saudi and Kuwaiti oil in some measure suggests that if possible it would have completely blocked the sea lanes to the Gulf. See Jenkins, stpra note 5, at 546; see also Bozcek, supra note 93 , at 51.

95. Fenrick, supra note 5, at 109-16 (complete description of British and Argentine exclusion zones). 
blockade zones because there were provisions for the protection of neutral shipping ${ }^{96}$ and because that area of the ocean was of limited commercial use. ${ }^{97}$

In all three wars, belligerents achieved balance between their interests and neutrals' interests by adjusting the size of the blockade area. The sizes were based on different combinations of the eight factors discussed, ranging from a full-scale, global war to a small, regional war with major consequences for neutral commerce. On a continuum, the blockades ranged from one extreme where large belligerent objectives and capabilities outweighed the needs of weaker neutral states, resulting in huge blockade areas, to the other extreme where the overwhelming needs and capabilities of neutral states forced belligerents to restrict greatly the size of the blockade area.

\section{The Weapons Decision}

The choice of weapons used to enforce a blockade also affects its size. Today, states generally employ either land, air, or surface launched missiles, nuclear- or diesel-powered submarines, high-speed jet aircraft, surface warships, a variety of sophisticated mines, or some combination thereof to enforce their blockade. ${ }^{98}$ As presented in Part II, blockading states face a stark choice: they can either use surface ships and enforce a long-distance blockade or employ other weapons and establish a blockade zone. Looking more closely, however, the choice is not so well defined. For each weapon, the burden on neutral vessels varies with the weapon's ability to discriminate between targets. As a result, the size of the blockade corresponds to the burden placed on neutrals by the particular enforcement weapon used. For example, surface ships firing missiles place a greater burden on neutral vessels than do surface ships visiting and searching. Thus, states firing missiles, even though they use surface ships, will enforce smaller blockades. Similarly, states firing missiles from surface ships conduct smaller blockades than states using submarines because missiles place greater burdens on neutral ships than torpedoes.

In the Cuban Missile Crisis, the United States declared a large stretch of ocean around Cuba off-limits to ships carrying ballistic missile components. The United States enforced the blockade with surface vessels visiting and searching merchants suspected of carrying the components. ${ }^{99}$ Those ships free of contraband could pass through the blockade, while those carrying contraband

96. Merchant vessels were permitted to pass through the zones uninspected, provided the merchants announced their intended routes beforehand. See Virginia Morris, Sovereign Immunity for Military Activities on the High Seas: Amerada Hess v. Argentine Republic, 23 INT'L L. 213 (1989) (only three neutral ships attacked during conflict).

97. See Fenrick, supra note 5, at 114 (Argentina and Soviet Union only states to protest British zones).

98. Richard Grunawalt, Transcript, The Rights of Neutrals and Belligerents, in Conference Report, The Persian/Arabian Gulf Tanker War: International Law or International Chaos, in 19 OCEAN DEV. \& INT'L L. 299, 307 (1988).

99. See Christol \& Davis, supra note 68 , at 527. 
were turned away. Since the use of warships to visit and search placed a small burden on neutrals, few protested the large blockade area.

During the Vietnam War, the United States mined Haiphong Harbor to interdict merchant traffic heading to North Vietnam. Because of the potentially devastating effects of these mines on neutral merchant vessels, the United States purposely placed its mines within North Vietnamese territorial waters ${ }^{100}$ and used its warships to warn away merchants. Since no neutral vessels heading to neutral ports were $\operatorname{los}^{101}$ and the blockade area was small, few neutral states objected to the mining practice.

In contrast, in the Iran-Iraq war both the Iranians and the Iraqis used missiles launched from over the horizon to interdict their opponent's merchant traffic. These missiles frequently hit targets far outside the declared blockade zones, resulting in significant losses to neutral merchant vessels. ${ }^{102}$ In response, powerful neutral nations entered the Persian Gulf to escort neutral vessels and effectively restrict the size of the area in which these damaging practices were conducted. ${ }^{103}$

In each of these conflicts, belligerents reduced the size of the blockade area as the burden placed on neutral vessels increased. ${ }^{104}$ This burden was directly proportional to the ability of a particular weapon system to distinguish between neutral and belligerent targets. More specifically, since the mine discriminates the least of the blockade weapons, followed by the missile, the torpedo, and the surface ship gun - which arguably discriminates the most-belligerents reduce blockade size as they shift their mode of enforcement from the most to least discriminating.

\section{B. The New Guiding Principles of Blockade}

Having examined post-WWI state practice, we now have an understanding of the relationship between the nine decisionmaking factors and blockade size. Consequently, we are now able to articulate the principles of modern blockade law. Since WWI, three guiding principles of blockade have emerged -impartiality, notice, and reasonableness. The principle of impartiality remains unchanged from its traditional understanding and therefore will not be

100. The United States was particularly concerned with preventing sinkings of ostensibly neutral Soviet merchant vessels to avoid escalation of the conflict. See O'CONNELL, supra note 10, at 94; see also Frank Swayze, Traditional Principles of Blockade in Modern Practice, 29 JAG J. 143, 163 (1977).

101. O'CONNELL, supra note 10 , at 95.

102. Jenkins, supra note 5 , at 546.

103. See generally Scott Davidson, United States Protection of Reflagged Kuwaiti Vessels, 4 INT'L J. ESTUARINE \& COASTAL L. 173 (1989); Ronald O'Rourke, Gulf Ops, U.S. NAVAL INST. PROC, Naval Rev. 1989, at 42; Margaret Wachenfeld, Reflagging Kuwaiti Tankers, 1988 DUKE L.J. 174.

104. Missiles launched from over the horizon and unmoored mines drifting with the current are more likely to accidently impact neutral vessels than are torpedoes or guns which have short ranges and require identification of the target before firing. 
discussed further. ${ }^{105}$ The principle of notice remains close to its traditional understanding, although its requirements have become more specific so it will be discussed briefly. Most importantly, the traditional principles of establishment, effectiveness, and respect for neutral rights have been replaced with an entirely new principle: reasonableness. Reasonableness dictates the size of the blockade. Because decisionmakers have a range of options as to how to conduct a blockade, the new principle provides guidance for delineating blockade size given the options chosen. In this manner, the law retains flexibility to guide state practice in the varied environment of modern conflict.

By enunciating the law, blockading states are more likely to make enlightened decisions in establishing and conducting blockades. By adhering to the principles over time, state expectations of appropriate behavior will be enhanced, reducing misunderstanding and unnecessary conflict between belligerent and neutral states.

\section{The Principle of Notice}

Before discussing the new principle of reasonableness, a short comment on the modern notice requirement should be made. The new concept of notice replaces both the traditional principle of notice and portions of the principle of establishment. Initial notice is still given through formal diplomatic channels to all states, but greater specificity is required to make the zone's boundaries clear to neutral vessels since surface ships no longer demarcate them. ${ }^{106}$ Blockaders are also expected to state generally the intended method of blockade enforcement. ${ }^{107}$ Under the new principles, the method of enforcement is critical to a determination of the proper size of the blockade and, therefore, to its lawfulness.

\section{The Principle of Reasonableness}

The principle of reasonableness requires states to conduct blockades of reasonable size. State decisionmakers determine reasonable size for each conflict by examining the nine decisionmaking factors. Theoretically, by considering each of these factors in formulating their blockade, decisionmakers will come up with a reasonably sized blockade that maintains an acceptable balance between belligerent and neutral interests. While valuable as theory, the process alone tells decisionmakers little about the appropriate size of a blockade for a given set of circumstances. Examining these nine decisionmaking factors

105. See discussion supra Part I.A (discussing traditional principles).

106. Clark, supra note 78, at 164-65 (detailed notice provided by the United States in the Cuban Missile Crisis and in the mining of Haiphong Harbor greatly reduced the damaging effects of blockade); see also Fenrick, supra note 5, at 124 (calling for greater specificity when giving notice).

107. See, e.g., Clark, supra note 78, at 174. 
in the context of actual practice, however, makes international expectations of what constitutes a reasonably sized blockade more explicit. The following sections guide state decisionmakers in determining a reasonable size for a blockade in the particular circumstances of their conflict.

(i) The Starting Point:Determining Maximum and Minimum Blockade Size. The first step in determining reasonable size is to recognize that there are internationally accepted bounds for maximum and minimum blockade size. The minimum reasonable size is the enemy's territorial waters, a twelve-mile strip of ocean measured out from the enemy's coastline. ${ }^{108}$ States treat territorial waters much like their own land and traditionally restrict passage through them during war. By analogy, since belligerents have always been able to restrict neutral access to enemy territory they control, they must also be able to restrict neutral use of the enemy's territorial waters. ${ }^{109}$

At the other extreme, two rules govern the maximum reasonable size of a blockade. First, the blockade may not encompass the territorial waters of a neutral state. ${ }^{110}$ Because territorial waters are like a state's land, neutral territorial waters are inviolate. Second, the blockade cannot completely bar neutral access to neutral ports. This second requirement is certainly borne out by postWW II conflicts-in none of these conflicts has neutral access to neutral ports been barred without strong neutral protests. ${ }^{111}$

For blockades falling between the maximum and minimum limits, states must make complex determinations of reasonableness. In these cases, state decisionmakers should determine reasonableness by examining the nine factors according to the following guidelines.

(ii) The First Guideline: Proportionality. Blockade size must be proportional to the ambitiousness of the objectives of the blockading state. ${ }^{112}$ In general, proportionality requires that the level of destruction be proportional to the military value of the objective sought. ${ }^{113}$ When applied to blockades, a small blockade zone is required where a blockader maintains limited objectives. As the blockader's objectives become more ambitious, the size of the blockade may expand. For example, both World Wars contained highly capable opposing belligerent navies attempting to interdict all commerce to their opponents' coasts across huge expanses of ocean. The ambitious objectives were justified,

108. NAVAL WARFARE DEP'T, NWP 9, at 1-5 (1983).

109. The territorial limit also makes a good starting point because it is a boundary well understood by states.

110. Belligerents are forbidden to use neutral territories to conduct hostilities. Hague Convention XIII Concerning the Rights and Duties of Neutral Powers in Naval War, Oct. 18, 1907, Art. 5, reprinted in Schindler \& Toman, supra note 18, at 952; see also Declaration of London, supra note 20, art. 1.

111. In the extreme of global conflict such a requirement will probably be ignored.

112. The guideline draws from two concepts in the law of land warfare. Proportionality in land warfare law refers to the relation between the amount of destruction effected and the military value of the objective sought. Relevancy requires that the destruction go toward realizing legitimate objectives. Relevancy is determined by examining the nexus between the destructive act and military necessity. MCDOUGAL \& FELICIANO, supra note 80 , at 524 .

113. Id. 
and thus the blockades were huge. In contrast, the Indo-Pakistani conflict involved a decidedly smaller Indian navy attempting to interdict commerce to Pakistan using large portions of the Indian Ocean. The Indians used submarines and missiles to enforce the zone, which led to the sinking of at least one neutral vessel and the damaging of several others. ${ }^{114}$ Given the more limited Indian objective of making East and West Pakistan separate sovereign states and the burden the blockade placed on neutrals, the United States, Great Britain, and other maritime powers protested the blockade and began measures to force a reduction in its size. Nonetheless, a quick end to the conflict and suspension of the blockade prevented direct neutral military action.

(iii) The Second Guideline: High Probability of Severe Damage. Modern blockades must ensure a high probability of severe damage to vessels entering the blockaded area. ${ }^{15}$ The German blockade of Great Britain during WWI provides a good example. Early in the war, the Germans attempted to interdict all merchant traffic to Great Britain by declaring a blockade zone around the islands. Yet the Germans did not have a large enough submarine fleet to enforce the zone effectively. Because the risk of destruction from entering the zone was low, neutral states continued to send their ships to England. Following the sinking of several neutral ships and fearing retaliation from neutral states, particularly the United States, the Germans discontinued the practice for six months. Later, the desperate circumstances of the war drove the Germans to disregard neutral interests and to reinstitute the blockade zone.

This guideline is probably the most important in ascertaining reasonable size. By ignoring the need to devote sufficient resources to make the entire blockaded area dangerous, state decisionmakers are more likely to declare a large expanse of ocean off-limits and thereby to place heavy burdens on neutral states. Large size and inadequate enforcement decrease the probability of destruction within the zone. With a small risk of destruction, neutral states are less willing to shoulder the burden of having to traverse around the large zone and are more likely to venture through it. When neutrals ignore the zone and risk destruction, the likelihood of conflict escalation increases as the need for neutral navies to enter the area to protect their merchant vessels grows.

(iv) The Third Guideline: Neutral Needs. Blockading states reduce the size of the blockade as the importance of the area to neutrals increases. ${ }^{116}$ In the Iran-Iraq war, Iran held ambitious objectives. Nonetheless, Iran maintained a smaller-sized blockade than it desired to account for the neutrals' need of

114. 2 O'CONNELL, supra note 4, at 1099; see also O'CONNELL, supra note 10 , at 86-87.

115. While this guideline resembles the traditional blockade principle of effectiveness, the two principles are not the same. Effectiveness under traditional blockade law refers to the probability of capturing merchant vessels by blockading surface forces. As previously discussed, given the conditions of the modern maritime battlefield, capture is much less likely than indiscriminate attack, so the standard must be shifted to the probability of substantially damaging vessels entering the zone.

116. See MALLISON, supra note 4, at 27 (neutral interests should limit amount of belligerent coercion employed). 
continued oil flow through the Straits of Hormuz. In contrast, the British blockade of the Falklands encompassed a huge portion of the South Atlantic given its limited objectives. Because few neutrals needed the area, for commerce or otherwise, few states protested the size or existence of the zone.

(v) The Fourth Guideline: Neutral Strength. In cases involving a large disparity between neutral and belligerent maritime strength, state decisionmakers must adjust blockade size to account for the differences. ${ }^{117}$ Where neutrals are strong, blockading states carefully consider the amount of risk they are willing to take in provoking neutral response. ${ }^{118}$ Decisionmakers consider the consequences of miscalculating reasonable size and ensure that the size is small enough that the blockading state can endure the consequences of the expected neutral response. Blockading states reduce the risk of overwhelming response by decreasing blockade size.

(vi) The Fifth Guideline: Military Necessity. Belligerents decrease the size of their blockade as the ability of the enemy to counter the blockade diminishes. In general, the law of military necessity requires military forces to achieve their legitimate objectives with the minimum amount of violence. For blockade, the guideline prevents unnecessary expansion of the blockade when the conflict does not warrant such expansion. While there are no modern examples of this guideline in action, the following is a hypothetical example of a violation. A powerful regional maritime state $A$ becomes angry with a small island nation $B$ because $B$ 's government refuses to curtail its fishing vessel violations of state $A$ 's exclusive economic zone. Frustrated by the failure of peaceful attempts to stop $B$ 's violations, state $A$ declares a blockade around $B . B$ maintains a police force but no army or navy and certainly no sophisticated weapons to use against $A$ 's blockading forces. Despite island $B$ 's grossly inferior military forces and complete inability to thwart a surface ship enforced close-in blockade, State $A$ decides to conduct a long-distance blockade which hinders not only $B$ 's trade, but also that of neutral states which are forced to travel great distances around the blockade. Because state $A$ can meet its legitimate military objectives without harassing neutral trade, its actions violate this guideline.

(vii) The Sixth Guideline: Method of Enforcement. The less discriminatory the method of blockade enforcement, the smaller states must make their blockades. A larger area is permitted for visit and search than for blockade zones. Within the blockade zone, the ability of the enforcement weapon to discriminate between belligerent and neutral, warship and merchant, affects the burden placed on neutrals. ${ }^{119}$ For example, a submarine can identify a merchant ship

117. "It is not realistic to think that minor belligerents would be permitted to disrupt the peaceful activities of the world community by the employment of extensive military techniques." MALLISON, supro note 4 , at 27.

118. See, e.g., H.W. Malkin, Blockade in Modern Conditions, 3 BRIT. Y.B. INT'L L. 87, 97 (1922-23).

119. Emphasis on the discriminating ability of the weapon, as opposed to the weapon itself, is important for the continued viability of the guideline because technological developments change a weapon's ability to discriminate. In addition, more specific articulation of weapon types will become important in the future 
before shooting at it. Missiles fired over the horizon and mines, however, do not provide such a luxury. Missiles have long ranges, which means they can stray far from the zone to hit an unintended target. Similarly, mines also have a tendency to break away from their moorings and drift with the current. In practice, therefore, belligerents reduce the size of the blockade area as they shift their enforcement method from submarine to missile to mine.

(viii) The Seventh Guideline: Accommodation. The seventh guideline provides for cases where states make special accommodations for neutrals traveling to neutral states. In these cases, where the blockading power explicitly provides for safe passage through the zone, it may expand the blockade zone. By allowing neutral passage through their respective zones, conditioned upon prior approval, the British and Argentineans in the Falklands conflict quelled neutral protest of what would otherwise have been considered large blockade zones. Since neither blockade obstructed peacetime shipping lanes, neutrals were not unduly burdened by the blockade.

When considered together, the seven guidelines reflect the common understanding that lawful blockades do not unreasonably restrict a neutral's right to engage in neutral commerce. Decisionmakers who understand this fundamental purpose of blockade law and follow the guidelines with this purpose in mind will significantly reduce the risk that their conflicts will grow to include neutral forces.

\section{CONCLUSION}

This Note has clarified the existing law of blockade by examining state blockade practice over the last seventy years. The evolution of this practice has been largely driven by the introduction of new naval weapons which have steadily forced maritime nations to discard traditional close-in blockades for either long-distance blockades or blockade zones. Because of this radical change in practice, states, through a complex process of give and take on the maritime battlefield, have adjusted the law to ensure the balance between neutral and belligerent interests is maintained. As a result, instead of a law that closely regulates how a blockade is established and enforced, the modern law regulates the size of the area in which a blockade is conducted. In this way, the law remains flexible enough to accommodate the large variance in the capabilities, objectives, and weapons of today's modern conflicts.

As time passes, the need for the powerful maritime nations to explicitly recognize and enforce this new law of blockade grows. The recent explosion in the size of developing countries' navies suggests that they will begin to assert themselves more aggressively on the ocean. The end to the Cold War

as missiles and mines become more sophisticated. As this happens, different missile types or different mine types will have widely varying abilities to discriminate between targets. 
also raises the probability of increased conflict at sea as the world adjusts to a new order. By explicitly acknowledging and consistently enforcing modern blockade law, the powerful states can reinforce existing expectations of appropriate blockade behavior and slow the seemingly inevitable trend toward greater violence at sea. 